\title{
Vietnam Economic Structure Change Based on Vietnam Input-Output Tables 2012 and 2016
}

\author{
Nguyen Ho Phi Ha1, Bui Trinh ${ }^{2 *}$ \\ ${ }^{1}$ Academy of Finance, Hanoi, Vietnam \\ ${ }^{2}$ Vietnam Development Research Institute (VIDERI), Hanoi, Vietnam \\ Email: p.nguyenho@yahoo.com.vn, *buitrinhcan@gmail.com
}

How to cite this paper: Ha, N.H.P. and Trinh, B. (2018) Vietnam Economic Structure Change Based on Vietnam Input-Output Tables 2012 and 2016. Theoretical Economics Letters, 8, 699-708. https://doi.org/10.4236/tel.2018.84047

Received: January 30, 2018

Accepted: March 5, 2018

Published: March 8, 2018

Copyright ( 92018 by authors and Scientific Research Publishing Inc. This work is licensed under the Creative Commons Attribution International License (CC BY 4.0).

http://creativecommons.org/licenses/by/4.0/

\section{cc) (7) Open Access}

\begin{abstract}
National economic structure is defined as the composition and patterns of various components of the national economy such as: production, value added, consumption, gross capital formation, export, import and gross value added. Structural change is conceptualized as the change in relative importance of the aggregate indicators of the economy. It implies that changes of intra-sectoral and inter-sectoral lead to changes in final demand, output, value added and import. This paper seeks to answer some questions: 1) What would be the impact on the power of dispersion and the sensitivity of dispersion by sectors? 2) What would be the impact on value added induced by final demand? and 3) How would the final demand impact the level of import? The main finding in this study is to find a sectoral structure and a factor of the final demand for Vietnam's development.
\end{abstract}

\section{Keywords}

Power of Dispersion, Sensitivity of Dispersion, Value Added, Final Demand, Import, Consumption Gross Capital Formation, Export

\section{Introduction}

In Vietnam, it has been politically directed and generally accepted that the structure of economy should be adjusted toward larger proportions of industry and construction sector (Sector II) and service sector (Sector III) in GDP and this has long been considered as the holistic solution to boost economic development [1]. Accordingly, the government has taken various measures to promote both Sector II and Sector III. The capital stock of the manufacturing industry has been rising and is estimated to account for over 53\% of the economy's total balance of payments. Nevertheless, the generous investments in the sector 
do not seem to be well paid off as the $\mathrm{n}$ value added-production ratio of this sector (Sector II) has fallen dramatically. This rate went down from $34.1 \%$ in the structure of 2007 (the structure of the I/O 2016 table) to only $21 \%$ in 2016 [2]. This means that this sector is increasingly inefficient and less productive, leading to an increase in investment to compensate for such inefficiencies.

The economic structure was proposed by W. Leontief [3] to analyze the structural change of the US economy based on the 1919 and 1929 input-output tables. Since then the input-output analysis has been developed by many models such as W. Leontief [4], Schoonbeek, L. [5], Ebiefung, A.A., Udo, G. [6], Dobos, I. and Floriska, A. [7], this study discussed some key features of the Vietnamese economic structure which are indicated by absorption matrices, which were developed by Chenery and Watanabe [8]. Inter-sectoral structure is determined through intermediate consumption and the relationship between final demand and gross output, added value and import.

In Vietnam, there are some studies that apply the input-output model to analyze and measure economic structure such as T. Bui, K. Kobayashi [9], T. Bui and Phong N.V. [10], Tran et al. [11], Nguyen P. Thao [12], T. Bui and Hoa P.L. [13].

\section{Data Source and Processing Method}

This paper uses the Vietnam input-output tables of 2012 and 2016. The 2012 input-output table was published by Vietnam General Statistics Office [14]. The input-output table 2016 was updated based on input-output table 2012 and the 2016 enterprise survey data of Vietnam General Statistics Office. The approach for updating is as follow:

- Determine the new gross output $\left(X^{2016}\right)$ based on the enterprise survey;

- Determine the vector of intermediary input $\left(I 2^{2016}\right)$ based on the enterprise survey;

- Intermediate input matrix:

$$
X_{i j}^{2016}=\left(X_{i j}^{2012} / I I_{j}^{2012}\right) * I I_{j}^{2016}
$$

In this method: $A^{2016} \neq A^{2012}$

where: $A=\left(a_{i j}=X_{i j} / X_{j}\right)_{(n \times n)}$ with $n$ is number of sectors in the input-output table;

- The final consumption is estimated based on the Household Living Standard Survey, investment, import and export of goods and services data collected from Vietnam General Statistics Office [15];

- The input-output table 2016 was adjusted to 2012 price;

- After that, RAS method was used to balance the input-output table 2016;

- In order to be compatible with the input-output tables of some Asian countries and available data for updating input-output table 2016, the research team selected 19 sectors (Table 1). 
Table 1. Sectors selected for the study.

\begin{tabular}{ll}
\hline N. & \\
\hline 1 & Agriculture, forestry and fisheries \\
2 & Extractive \\
3 & Production of food, beverages and cigarettes \\
4 & Production of textile products, apparels and leather goods \\
5 & Production of petroleum products and gas \\
6 & Production of chemical products \\
7 & Production of non-metallic mineral products \\
8 & Manufacturing and processing metals and metal products \\
9 & Manufacturing equipment and machinery \\
11 & Other manufacturing industries \\
11 & Production and distribution of electricity, gas, hot water, steam and air conditioning \\
12 & Water supply; Waste and waste water management and treatment \\
13 & Construction \\
14 & Transportation of warehouses \\
15 & Trading, retail; hotel and restaurant \\
16 & Information and communication \\
17 & Financial, banking and insurance operations \\
18 & Professional, scientific and technological activities \\
19 & Other service industries \\
\hline
\end{tabular}

Source: Selected by authors.

\section{Methodology}

The input-output tables of Vietnam were compiled with competitive-import type, this means the intermediate input matrix, final consumption, gross capital formation and export cover both domestic products and import products. In order to better understand the economic structure, the input-output tables with competitive-import type should convert to non-competitive-import type. The way for moving is as below:

Leontief standard equation at competitive-import type::

$$
A \cdot X+Y=X
$$

where $X$ is the gross output matrix, $A=\left(a_{i j}\right)_{(n \times n)}$ is the direct intermediate input coefficient matrix with $a_{i j}=X_{i j} / X_{j}, Y$ is the domestic final demand matrix and $n$ is the number of sectors.

$$
Y=C+G+I+E-M
$$

where: $C$ is final consumption of household, $G$ is Government consumption. $I$ is gross capital formation, $E$ is export and $\mathrm{M}$ is import. Decompose matrix $A$ and $Y$ for domestic $\left(A^{d}, Y^{t}\right)$ and imported products $\left(A^{m}, Y^{m}\right)$, Equation (1) can be rewritten: 


$$
A^{d} \cdot X+A^{m} \cdot X+C^{d}+C^{m}+G^{d}+G^{m}+I^{d}+I^{m}+E=X
$$

Call $C^{d}+G^{d}+I^{d}+E=Y^{d}$

And notice that $A^{m} \cdot X+C^{m}+G^{m}+I^{m}=M$

From Equations (1)-(3) we have:

$$
A^{d} \cdot X+Y^{d}=X
$$

And the Leontief equation to the non-competitive input-output model is:

$$
X=\left(I-A^{d}\right)^{-1} \cdot Y^{d}
$$

$A^{d}$ is the matrix of the direct domestic intermediate input ratio, $\left(I-A^{d}\right)^{-1}$ is the inverse Leontief matrix and $Y^{d}$ is the domestic final demand matrix (including final consumption of domestic products, accumulation of domestic products and exports).

Put: $B=\left(I-A^{d}\right)^{-1}$.

The backward linkage (BL) and forward linkage (FL) are defined as follows:

Backward linkage:

$B_{j}=\sum_{i}^{n} B_{i j}$; Refers to the expansion of an industry when using other industry products as inputs.

\section{Forward linkage.}

$B_{i}=\sum_{j}^{n} B_{i j}$ indicates the level of production depending on input from other sectors.

Guo and Hewings [16] argued that increased backward linkage will generate greater demand for inputs by other industry and increased forward linkages will lead to changes in output sensitivity in other sectors.

Accordingly, the power of dispersion index and the sensitivity for dispersion of each sector are determined as below:

Power of dispersion index:

$$
P_{j}=B_{j} \cdot(N / T)
$$

Sensitivity for dispersion index.

$$
S_{i}=B_{i} \cdot(N / T)
$$

Here $T=\sum \sum B_{i j}$.

The combination of sensitivity and dispersion of each sector indicates the relative importance of that sector to the economy. This combination is defined as the "multiplier product matrix" of the Leontief system:

$$
M=S \cdot P
$$

With: $S=\left(S_{i}\right)_{(n \times 1)}$ and $P=\left(P_{j}\right)_{(1 \times n)}$ and $M=\left(M_{i j}\right)_{(n \times n)}$ are considered as "Economic-Landscape" at a given time and indicate the inter-sectoral structure at that time.

The effect of demand on output $X$ and value added is calculated as follows:

Impact of final domestic demand on output $X: \Sigma\left(I-A^{d}\right)^{-1} \cdot Y^{d} \div \Sigma Y^{d}$

Impact of final domestic demand on value added $\Sigma v \cdot\left(I-A^{d}\right)^{-1} \cdot Y^{d} \div \Sigma Y^{d}$

Here: $\div$ shows scalar division 


\section{Research Results}

\section{About power of dispersion index and sensitivity for dispersion index}

The results of the research on power of dispersion index and sensitivity for dispersion index from Table 2 show that industry group of agriculture, forestry and aquatic product (Sector 1), industry group of food processing, beverage and tobacco (Sector 3), the production of oil and gas products (Sector 5) and other manufacturing industries (Sector 10) have both power of dispersion index and sensitivity of dispersion index higher than the general average of the economy and there is no change in the two I/O tables, which suggests that these four groups of manufacturing sectors not only strongly stimulate other groups of industry of the economy, but the input demand for the economy is also large. Most service industries do not have good power of dispersion index and sensitivity, especially in sector 18 (Professional, scientific and technological activities) of which both the power of dispersion and sensitivity are significantly lower than average, suggesting that this industry group does not impact on others and other industries do not depend on it.

Table 2. Power of dispersion and sensitivity of dispersion indexes of economy.

\begin{tabular}{|c|c|c|c|c|c|c|c|c|}
\hline No. & $\begin{array}{c}\text { Backward } \\
\text { linkage } \\
(\mathrm{BL})\end{array}$ & $\begin{array}{l}\text { Power of } \\
\text { dispersion }\end{array}$ & $\begin{array}{c}\text { Forward } \\
\text { linkage } \\
(\mathrm{FL})\end{array}$ & $\begin{array}{c}\text { Sensitivity } \\
\text { of } \\
\text { dispersion }\end{array}$ & $\begin{array}{c}\text { Backward } \\
\text { linkage } \\
(\mathrm{BL})\end{array}$ & $\begin{array}{l}\text { Power of } \\
\text { dispersion }\end{array}$ & $\begin{array}{c}\text { Forward } \\
\text { linkage } \\
(\mathrm{FL})\end{array}$ & $\begin{array}{c}\text { Sensitivity } \\
\text { of } \\
\text { dispersion }\end{array}$ \\
\hline 1 & 1.688 & 1.104 & 2.299 & 1.504 & 2.181 & 1.109 & 3.18 & 1.616 \\
\hline 2 & 1.396 & 0.913 & 2.219 & 1.452 & 1.761 & 0.895 & 2.7 & 1.373 \\
\hline 3 & 2.263 & 1.48 & 1.657 & 1.084 & 2.769 & 1.408 & 2 & 1.017 \\
\hline 4 & 1.551 & 1.014 & 1.364 & 0.892 & 1.968 & 1 & 1.658 & 0.843 \\
\hline 5 & 1.749 & 1.144 & 1.923 & 1.258 & 2.207 & 1.122 & 2.994 & 1.522 \\
\hline 6 & 1.558 & 1.019 & 1.461 & 0.955 & 2.128 & 1.082 & 2.164 & 1.1 \\
\hline 7 & 1.582 & 1.035 & 1.304 & 0.853 & 2.153 & 1.094 & 1.693 & 0.861 \\
\hline 8 & 1.464 & 0.957 & 1.752 & 1.146 & 1.935 & 0.983 & 2.764 & 1.405 \\
\hline 9 & 1.377 & 0.901 & 1.294 & 0.846 & 1.747 & 0.888 & 1.977 & 1.005 \\
\hline 10 & 1.778 & 1.163 & 2.489 & 1.628 & 2.252 & 1.145 & 3.521 & 1.79 \\
\hline 11 & 1.183 & 0.774 & 1.337 & 0.874 & 1.505 & 0.765 & 1.563 & 0.795 \\
\hline 12 & 1.385 & 0.906 & 1.106 & 0.724 & 1.819 & 0.925 & 1.167 & 0.593 \\
\hline 13 & 1.697 & 1.11 & 1.153 & 0.754 & 2.11 & 1.073 & 1.229 & 0.625 \\
\hline 14 & 1.603 & 1.048 & 1.442 & 0.943 & 2.068 & 1.051 & 1.731 & 0.88 \\
\hline 15 & 1.466 & 0.959 & 1.722 & 1.126 & 1.905 & 0.968 & 2.23 & 1.134 \\
\hline 16 & 1.538 & 1.006 & 1.42 & 0.929 & 1.908 & 0.97 & 1.654 & 0.841 \\
\hline 17 & 1.363 & 0.892 & 1.546 & 1.011 & 1.775 & 0.903 & 1.917 & 0.974 \\
\hline 18 & 1.355 & 0.886 & 1.229 & 0.804 & 1.819 & 0.925 & 1.515 & 0.77 \\
\hline 19 & 1.271 & 0.831 & 1.353 & 0.885 & 1.679 & 0.854 & 1.597 & 0.812 \\
\hline
\end{tabular}

Source: Calculated by authors based on Vietnam input-output tables, 2012 and 2016. 
The combination of sensitivity and power of dispersion provides us a picture of inter-sectoral linkages, given that the I/O table 2012 represents the economic structure of period 2008-2013 and I/O table 2016 represents the economic structure of period 2014-2018. Figure 1 and Figure 2 below suggest that there has been very little or almost no changes in the inter-sectoral linkages during the last 10 years. Nevertheless, the level of efficiency presented by the value added-to-production ratio is lower during 2014-2018 than during 2008-2013 in most industries. The ratio calculated for 2013 based on 2012 input-output table was $36 \%$, but felt down to only $28 \%$ in a calculation based on 2016 table. The manufacturing and processing industries are those which experienced the most drastic reduction in this ratio. This reflects a declining level of production efficiency, particularly in processing industry group (Figure 3 ).

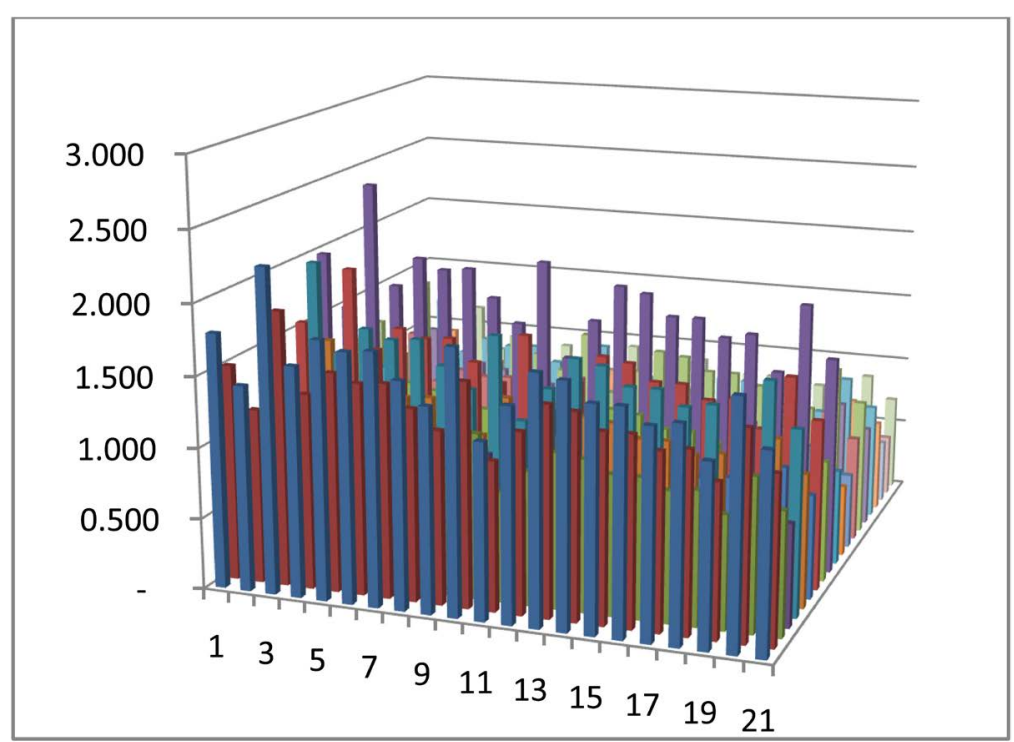

Source: Calculation of authors

Figure 1. The Economic-Landscape 2016.

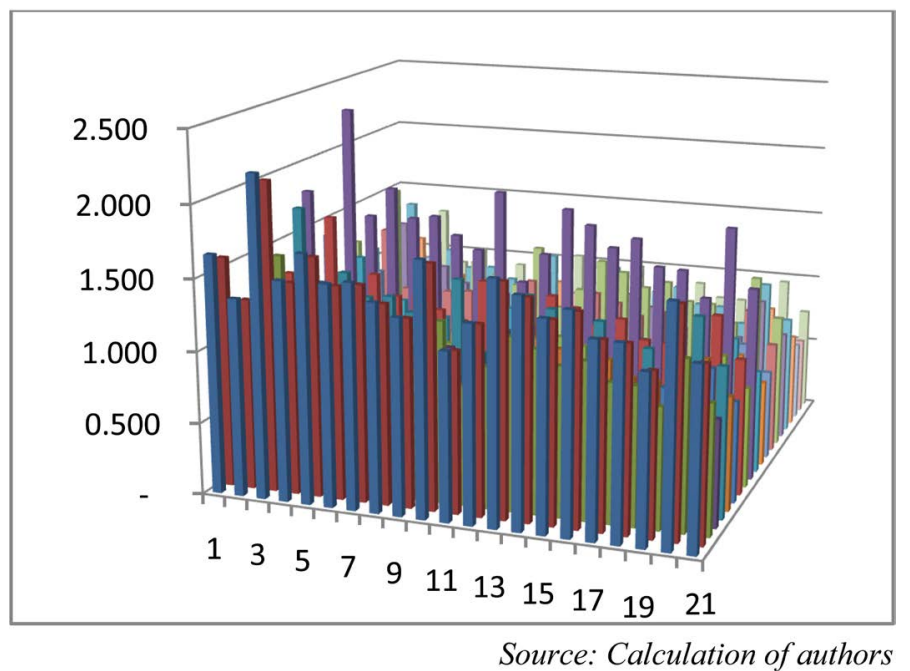

Figure 2. The Economic-Landscape 2012. 


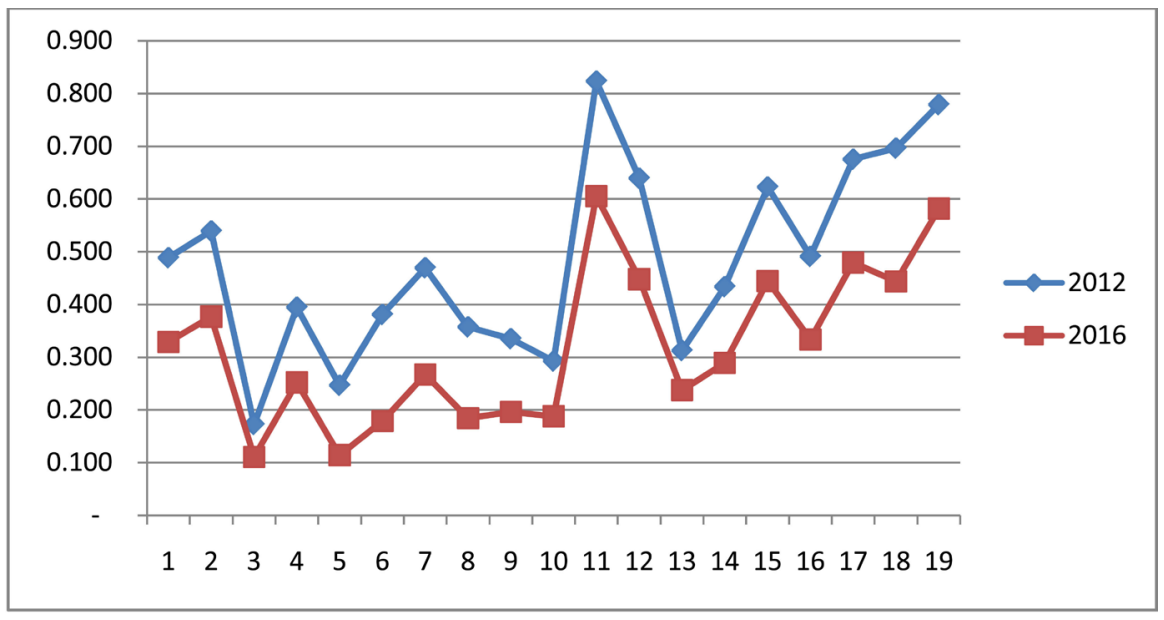

Source: Calculation of based onVietnam enterprises survey

Figure 3. Value added-to-production ratio.

\section{Value added and import induced by a unit increase in final demand}

So far the paper has only discussed the dispersion power of demand to production. In many cases, the increase in demand stimulates not only the domestic production but also the import and therefore has very limited impact on value added. A sector is considered to be relative important to the economy if this sector has a relatively strong power of dispersion and high sensitivity index but has low dispersion to imports and high dispersion to value added. In this regard, the paper provides a deeper analysis in 4 sectors which have high dispersion power and sensitivity indexes.

Table 3 shows that among these four sectors, only the sector group of agriculture, forestry and aquatic product satisfy requirement as important sector to the economy as mentioned above. Sector of manufacturing and processing industries, though having high power of dispersion and sensitivity index, also strongly stimulates imports and disperses to added value much lower than the average. This shows that the manufacturing and processing industry in Vietnam remains relatively weak and at the lower end of the value chain, majoring in processing rather than manufacturing.

It is also interestingly found that most service sectors have low power of dispersion and sensitivity index, but induce higher impact on value added and lower impact on import. This suggests that Vietnam should enhance capacity to produce input for service industries and likewise the services industries should be further developed to meet demand of other industries. By doing so, the improved dispersion power and sensitivity index would strengthen the inter-sectoral linkages, thus creating a strong impetus for country's economic development.

Table 4 shows that the structure of demand and supply tends to change unfavorably. The structure of 2016 indicates that the dispersion of demand factors to production is higher than that of 2012, however, the dispersion to the value added is lower while the dispersion to the import is stronger. Importantly, export of commodities has the lowest dispersion to the added value while having 
Table 3. Value added, import was induced by a unit increase in final demand.

\begin{tabular}{|c|c|c|c|c|c|c|}
\hline & & 2012 & & & 2016 & \\
\hline STT & $\begin{array}{l}\text { Value added } \\
\text { induced by a } \\
\text { unit increase of } \\
\text { final demand }\end{array}$ & $\begin{array}{c}\text { Power of } \\
\text { dispersion on } \\
\text { value added }\end{array}$ & $\begin{array}{c}\text { Power of } \\
\text { dispersion on } \\
\text { import }\end{array}$ & $\begin{array}{c}\text { Value added } \\
\text { induced by a } \\
\text { unit increase of } \\
\text { final demand }\end{array}$ & $\begin{array}{c}\text { Power of } \\
\text { dispersion on } \\
\text { value added }\end{array}$ & $\begin{array}{c}\text { Power of } \\
\text { dispersion on } \\
\text { import }\end{array}$ \\
\hline 1 & 0.684 & 1.024 & 0.952 & 0.640 & 1.050 & 0.922 \\
\hline 2 & 0.654 & 0.979 & 1.042 & 0.585 & 0.960 & 1.062 \\
\hline 3 & 0.625 & 0.935 & 1.130 & 0.580 & 0.953 & 1.074 \\
\hline 4 & 0.560 & 0.838 & 1.327 & 0.511 & 0.839 & 1.251 \\
\hline 5 & 0.483 & 0.722 & 1.560 & 0.431 & 0.707 & 1.456 \\
\hline 6 & 0.511 & 0.765 & 1.474 & 0.493 & 0.809 & 1.297 \\
\hline 7 & 0.663 & 0.992 & 1.016 & 0.619 & 1.016 & 0.975 \\
\hline 8 & 0.431 & 0.645 & 1.716 & 0.413 & 0.678 & 1.502 \\
\hline 9 & 0.388 & 0.581 & 1.845 & 0.375 & 0.615 & 1.600 \\
\hline 10 & 0.538 & 0.806 & 1.392 & 0.514 & 0.844 & 1.243 \\
\hline 11 & 0.879 & 1.316 & 0.364 & 0.763 & 1.253 & 0.606 \\
\hline 12 & 0.772 & 1.154 & 0.689 & 0.690 & 1.133 & 0.793 \\
\hline 13 & 0.578 & 0.864 & 1.274 & 0.538 & 0.883 & 1.183 \\
\hline 14 & 0.604 & 0.904 & 1.193 & 0.555 & 0.911 & 1.138 \\
\hline 15 & 0.798 & 1.195 & 0.608 & 0.724 & 1.189 & 0.706 \\
\hline 16 & 0.682 & 1.020 & 0.959 & 0.608 & 0.998 & 1.003 \\
\hline 17 & 0.869 & 1.300 & 0.396 & 0.798 & 1.309 & 0.517 \\
\hline 18 & 0.822 & 1.230 & 0.536 & 0.714 & 1.171 & 0.733 \\
\hline 19 & 0.886 & 1.325 & 0.345 & 0.799 & 1.311 & 0.515 \\
\hline
\end{tabular}

Source: Calculation of authors based on Vietnam input-output tables, 2012 and 2016, note: 19 sectors consistency with Table 1.

Table 4. Output, value added, import was induced by factor in Final demand.

\begin{tabular}{ccccccccc}
\hline & \multicolumn{3}{c}{2012} & \multicolumn{5}{c}{2016} \\
\hline & $\begin{array}{c}\text { Final } \\
\text { consumpt } \\
\text { ion }\end{array}$ & $\begin{array}{c}\text { Gross } \\
\text { capital } \\
\text { formation }\end{array}$ & $\begin{array}{c}\text { Export of } \\
\text { Goods }\end{array}$ & $\begin{array}{c}\text { Export } \\
\text { of } \\
\text { services }\end{array}$ & $\begin{array}{c}\text { Final } \\
\text { consumpt } \\
\text { ion }\end{array}$ & $\begin{array}{c}\text { Gross } \\
\text { capital } \\
\text { formation }\end{array}$ & $\begin{array}{c}\text { Export of } \\
\text { Goods }\end{array}$ & $\begin{array}{c}\text { Export of } \\
\text { services }\end{array}$ \\
\hline $\begin{array}{c}\text { Output } \\
\text { Value } \\
\text { added }\end{array}$ & 1.744 & 1.799 & 1,788 & 1.601 & 2.053 & 2.128 & 2.094 & 1.911 \\
Import & 0.72 & 0.58 & 0.56 & 0.76 & 0.66 & 0.54 & 0.52 & 0.69 \\
\hline
\end{tabular}

Source: Calculation of authors based on Vietnam input-output tables, 2012 and 2016.

strong dispersion to import. This again reaffirms the above finding that the country's economy has strong characteristic of a "processing economy" and the slogan "Vietnamese use Vietnamese goods" no longer holds true. 


\section{Conclusions}

The agro-forestry-fishery sector has good power of dispersion, sensitivity on production, the induced impact of final demand to value added. This sector needs capital and high-quality human resources as well as policy support to be able to develop sustainably.

The research results are similar to that of the research by Nguyen Hong Son in the study "2020 Vietnam Service: Towards Quality, Efficiency and Modernity" [17] as service sector has a good dispersion to income and less impacts on the greenhouse gas emissions, however, this sector have a low power of dispersion and sensitivity of dispersion indexes on production values. If the dispersion and sensitivity could be improved, it would positively impact on the quality and sustainability of growth. For the dispersion and sensitivity to increase, it's necessary to take a specific priority policy for the domestic supporting industries, particularly those that produce inputs to the service sector. Research shows that the most important resource for sustainable and rapid development is "policy resources".

It's necessary to take a flexible policy in dealing with the elements of the final demand. This study shows that currently, the export has no much dispersion on the value added. It just has the dispersion on the largest import.

The research should not focus too heavily on industry but on agriculture and services. The structure in priority order should be Services, Agriculture and finally Industrial. Moreover, it is necessary to gradually export goods by exporting services.

\section{References}

[1] Vietnam Government. (2015) To Increase the Proportion of Industries and Services in Order to Raise Labor Productivity.

http://baochinhphu.vn/Thu-tuong-va-Thanh-vien-Chinh-phu-tra-loi-chat-van/Tan g-ty-trong-cong-nghiep-dich-vu-de-nang-cao-nang-suat-lao-dong/220397.vgp

[2] Trinh, B. and Quoc, B. (2017) Some Problems on the Sectoral Structure, GDP Growth and Sustainability of Vietnam. Journal of Reviews on Global Economics, 6, 143-153. https://doi.org/10.6000/1929-7092.2017.06.12

[3] Wassily, L. (1941) Structure of the American Economy, 1919-1929. Harvard University Press, Cambridge, MA.

[4] Wassily, L. (1970) Environmental Repercussions and the Economic Structure: An Input-Output Approach. The Review of Economics and Statistics, 52, 262-271.

[5] Schoonbeek, L. (1990) The Size of the Balanced Growth Rate in the Dynamic Leontief Model. Economic Systems Research, 2, 345-349.

https://doi.org/10.1080/09535319000000024

[6] Ebiefung, A. and Udo, G. (1999) An Industrial Pollution Emission Control Model. Computers \& Industrial Engineering, 37, 371-374. https://doi.org/10.1016/S0360-8352(99)00096-0

[7] Dobos, I. and Floriska, A. (2005) A Dynamic Leontief Model with Non-Renewable Resources. Economic Systems Research, 17, 317-326.

https://doi.org/10.1080/09535310500221856 
[8] Chenery, H.B. and Watanabe, T. (1958) International Comparison of the Structure of Production. Econometrica, 26, 487-521.

[9] Trinh, B., Kobayashi, K., et al. (2012) Analyzing Some Economic Relations Based on Expansion Input-Output Model. International Journal of Business Performance Management, 7, 2012.

[10] Trinh, B. and Phong, N.V. (2013) A Short Note on RAS Method. Advances in Management \& Applied Economics, 3, 133-137.

[11] Tran, T., et al. (2016) Finding Economic Structure and Capital Structure for a “Greener” Economy. International Journal of Economic Research, No. 13, 3153-3167.

[12] Thao, N.P. (2014) An Analysis for the Northern Key Economic Region: Vietnam Based on the Input-Output Table Noncompetitive Style. Journal of Finance and Investment Analysis, 3, 37-47.

[13] Trinh, B. and Le Hoa, P. (2017) Comparing the Economic Structure and Carbon Dioxide Emission between China and Vietnam. International Journal of Economics and Financial Research, 3, 31-38.

[14] Vietnam GSO. (2015) Vietnam Input-Output Table, 2012. Statistical Publisher, Hanoi.

[15] Vietnam GSO. (2017) Statistical Yearbook. Statistical Publisher, Hanoi.

[16] Guo, D. and Hewings, G.J.D. (2001) Comparative Analysis of China's Economic Structures between 1987 and 1997: An Input-Output Prospective. Discussion Paper at Regional Economics Applications Laboratory, Urbana.

[17] Son, N.H. (2010) Service in Vietnam 2020: Towards Quality, Efficiency and Modernity. Hanoi National University Publishing House, Hanoi. 